\title{
IEDZĪVOTĀJU MIRSTİBAS TERITORIĀLĀ DIFERENCIĀCIJA BALTIJAS VALSTĪS
}

\section{Aleksandrs Dahs}

\author{
Latvijas Universitāte, e-pasts: aleksandrs.dahs@lu.Iv
}

\begin{abstract}
Anotācija. Pēdējās desmitgades laikā, Latvijā, līdzīgi kā citās Baltijas valstīs, gan politiskajā, gan akadēmiskajā vidē, arvien biežāk tiek pieminēta reǵionu depopulācijas problemātika. Kaut arī zinātniskajā literatūrā depopulācijas procesa migrācijas komponentei Latvijā tika pievērsta pietiekami plaša uzmanība, iedzīvotāju dabiskās kustības, un it sevišḳi - mirstības, loma iedzīvotāju skaita sarukumā Latvijas reǵionos ir salīdzinoši maz izpētīts lauks, ko līdz šim noteica ierobežots pieejamo statistisko un telpisko datu apjoms. 2011. gadā, Latvijā norisinājās pirmā tautas skaitīšana pēc 1999.-2009. gadu administratīvi-teritoriālās reformas, kas ne tikai parādīja patiesu reǵionu depopulācijas mērogu, bet arī pavēra plašākas iespējas reǵionālo demogrāfisko procesu analīzei atsevišḳu novadu līmenī. Ievērojot minēto, izmantojot 2011. gada tautas skaitīšanas rādītājus, kā arī citu pieejamo statistisko informāciju, autors veic iedzīvotāju mirstības rādītāju netiešo standartizāciju Latvijas pašvaldību līmen̄̄. Ar mērḳi izpētīt līdzīgu reǵionālo procesu tendences kaimiņvalstīs, autors realizē arī Lietuvas un Igaunijas apriņķu mirstības datu standartizāciju. Standartizācijas rezultātā iegūtiem datiem tiek pievienota telpiskā informācija, kas atvieglo to turpmāku grafisku reprezentāciju un analīzi. Mirstības datu statistiskās un telpiskās analīzes rezultāti norāda uz ievērojām atškirībām starp vīriešu un sieviešu mirstības rādītājiem vairākās teritoriālajās vienībās, kā arī ḷauj izdarīt secinājumu par statistiski nozīmīgu vīriešu mirstības telpisko autokorelāciju Latvijā.
\end{abstract}

Atslēgas vārdi: reg̣ionālā demogrāfija, iedzīvotāju mirstība, telpiskā analīze. 


\section{Ievads}

Pieejamie pēdējās desmitgades literatūras avoti un pētījumi identificē nozīmīgas reǵionālās demogrāfiskas problēmas Latvijā un tās reǵionos (Krišjāne 2006 vai Zvidriņš (ed.) 2009). Lielākā no tām ir atsevišķu teritoriālo vienību strauja depopulācija, kas notiek gan iedzīvotāju emigrācijas, gan negatīvā iedzīvotāju skaita dabiskā pieauguma ietekmē. Ir labi zināms, ka šāda situācija nav sveša arī Latvijas tuvākajām kaimiṇvalstīm - Lietuvai un Igaunijai (piem., Bērziņš, Zvidriņš 2011). Visās trīs Baltijas valst̄̄s 2011.2012. gadā tika tautas skaitīšana, kas parādīja patiesu reǵionu depopulācijas mērogu un sniedza labāku ieskatu par šo procesa cēloṇiem. Latvijā, 2011. gada tautas skaitīšana norisinājās vien 2 gadus pēc 1999.-2009. gada administratīvi teritoriālās reformas, un tās rezultāti pirmo reizi ḷāva veikt padziḷinātu demogrāfisko procesu analīzi atsevišḳu novadu un republikas pilsētu līmen̄i.

Vēl pirms tas tika skaitliski apstiprināts ar tautas skaitīšanas datu palīdzību, zinātnieki un valdība pievērsa lielu uzmanību iedzīvotāju emigrācijas lomai valsts un tās reǵionu depopulācijā (piem., Eglīte 2008). Savukārt iedzīvotāju dabiskās kustības procesu ietekme uz reǵionu iedzīvotāju skaita pārmaiṇām Latvijā palika otrajā plānā gan mazākas kopējās ietekmes, gan ticamu statistisku un telpisku datu trūkuma dēḷ. Standartizētā iedzīvotāju mirstība Latvijas reǵionos tika aplūkota 2006. gadā (toreizējo valsts rajonu līmenī) pētìjumā "Iedzīvotāju veselība, mirstība un mūža ilgums Latvijā: tendences, faktori, perspektīvas" (Krūmiņš 2006). Pētījums parādīja, ka pat lielāku teritoriālo vienību griezumā Latvijā pastāvēja ievērojamas atškirīibas starp reǵionu standartizētās mirstības līmeņiem. Savukārt 2009. gada pētījums "Changes of Geographical Mortality Differences in the three Baltic Countrie during the Period of Socio-Economic Transformation", sniedza padziḷinātu informāciju par standartizētās mirstības līmeṇiem un galvenajiem cēloṇiem visu trīs Baltijas valstu reǵionos, kā arī parādīja, ka aplūkotie iedzīvotāju standartizētie mirstības rādītāji ir atkarīgi no pētāmās teritoriālās vienības telpiskā izvietojuma (Krūmiņš et al. 2009).

Tādējādi, izmantojot pēdējo tautas skaitī̌sanu rādītājus, kā arī pieejamos reǵionālā un nacionālā līmeņa statistiskos datus par 2008.-2014. gada periodu, autors veic iedzīvotāju mirstības rādītāju netiešo standartizāciju Latvijas pašvaldību, kā arī atsevišķu apriņķu līmenī Lietuvā un Igaunijā. Iegūtie dati tiek analizēti gan grafiski, gan izmantojot telpiskās analīzes metodes.

Analīzes rezultāti parāda ievērojamas atšķirības starp vīriešu un sieviešu mirstības rādītājiem vairākās Latvijas teritoriālajās vienībās, kā arī l̦auj izdarīt secinājumu par statistiski nozīmīgu vīriešu mirstības telpisko autokorelāciju visās Baltijas valstīs. Šādu situāciju var izskaidrot ar to, ka vīriešu un sieviešu mirstības procesu vismaz daḹji ietekmē atšksirīgi sociāli ekonomiskie un vides faktori, kas ir raksturīgi noteiktām reǵionu grupām.

\section{Dati un metodes}

Kā jau tika minēts, pateicoties 2011. gada tautas skaitīšanai, Latvijas pētniekiem ir kḷuvuši pieejami demogrāfiskie dati atsevišķu valsts novadu un republikas pilsētu 
līmen̄i. Diemžēè šie dati neiekḷauj pietiekami detalizētus mirstības rādītājus, kas nosaka nepieciešamību veikt šo indikatoru standartizāciju. Izvērtējot pieejamus statistikas indikatorus Baltijas valstīs, autors izvelējās netiešās standartizācijas metodi, kas ir plaši aprakstîta literatūrā un tiek bieži lietota, pētot mazu teritoriālo vienību demogrāfiskos procesus. Par standartu izvēlētas katras valsts kopējās dzimuma un vecuma struktūras.

Lai uzlabotu iegūto standartizētu rādītāja vērtību ticamību sevišşi maziem novadiem (iedzīvotāju skaita ziṇā), autors izmanto 2011. (tautas skaitǐšanas) gadu par bāzes gadu, kā arī aprēķina un izmanto vidējos un / vai svērtos vidējos lielumus (par 2008.-2014. gada periodu) vairākiem standartizācijas procesā lietotiem indikatoriem: mirušo skaits pašvaldībās, mirstības koeficients valstī, mirušie pēc dzimuma un vecuma valstī (CSP 2016; Statistics Lithuania 2016; Statistics Estonia 2016). Pārrēḳinā izmantotu svaru lomā tiek lietoti katra attiecīgā gada vidējie iedzīvotāji attiecīgajā pašvaldībā. Standartizācijas rezultātā iegūtajiem datiem tiek pievienota telpiskā informācija, izveidojot G̦IS Shapefile datnes, kas atvieglo datu turpmāku grafisku reprezentāciju un telpisko analīzi.

Lai noskaidrotu telpisko sakarību klātbūtni iegūtajos datos, autors lieto Globālus un Lokālus telpiskās autokorelācijas testus, kas l̦auj apstiprināt vai noliegt hipotēzi par to, ka teritoriālās vienības ar līdzīgiem pētāmā rādītāja lielumiem tiecas veidot statistiski nozīmīgas telpiskās grupas jeb "karstus" un "aukstus" klasterus kartē (Voss et al. 2006). Piemēram, gadījumā, kad pašvaldības ar augstām indikatora vērtībām tiecas būt telpiski izvietotas visai tuvu viena otrai, var spriest par pozitīvu telpisko autokorelāciju reǵionā. Šādas autokorelācijas noteikšanai, praksē bieži lieto plaši pazīstamu "Morana I" (Morans's I) testu, ko savos darbos detalizēti aprakstīja Lūks Anselins (sk. Anselin 1995).

Papildus jau iegūtiem datiem, lai veiktu telpisko analīzi, ir nepieciešams kvantificēt teritoriālo vienību telpisko struktūru, ko var vienkārši paveikt, izveidojot kvadrātu telpisko svaru matricas (W) katrai no pētāmajām valstīm (kur n = teritoriālo vienību skaits valstī) (Matthews, Parker 2013).

\section{Analīzes rezultāti}

1. attēls, parāda kopējo, kā arī vīriešu un sieviešu standartizētās mirstības līmeni Baltijas valstu administratīvi teritoriālajās vienībās 2011. gadā. Ērtākai datu vizuālajai analīzei kartē attēlotie pētāmā rādītāja līmeṇi tika sadalīti vairākās statistiskajās kvantilēs. 

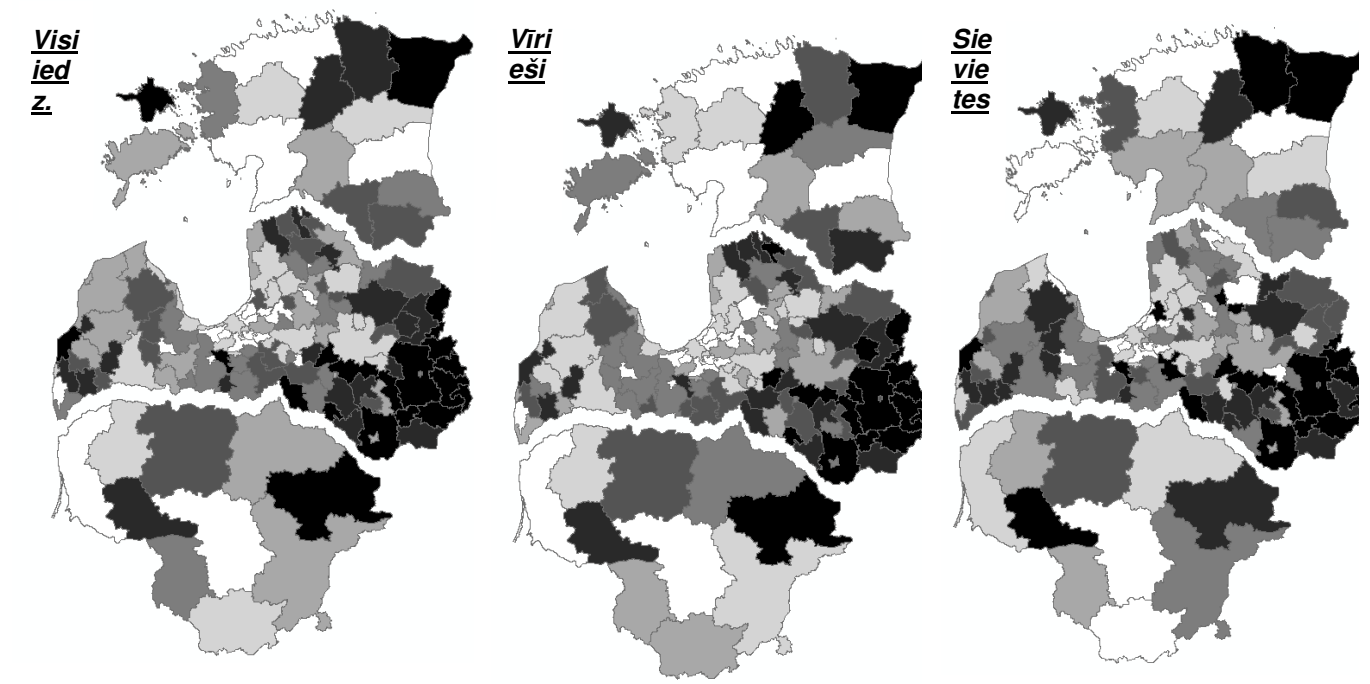

1. attēls. Standartizētās mirstības kvantiles Baltijas valstu administratīvajās vienībās

2011. gadā. Avots: CSP, Statistics Lithuania un Statistics Estonia datiem balstīti autora aprēķini

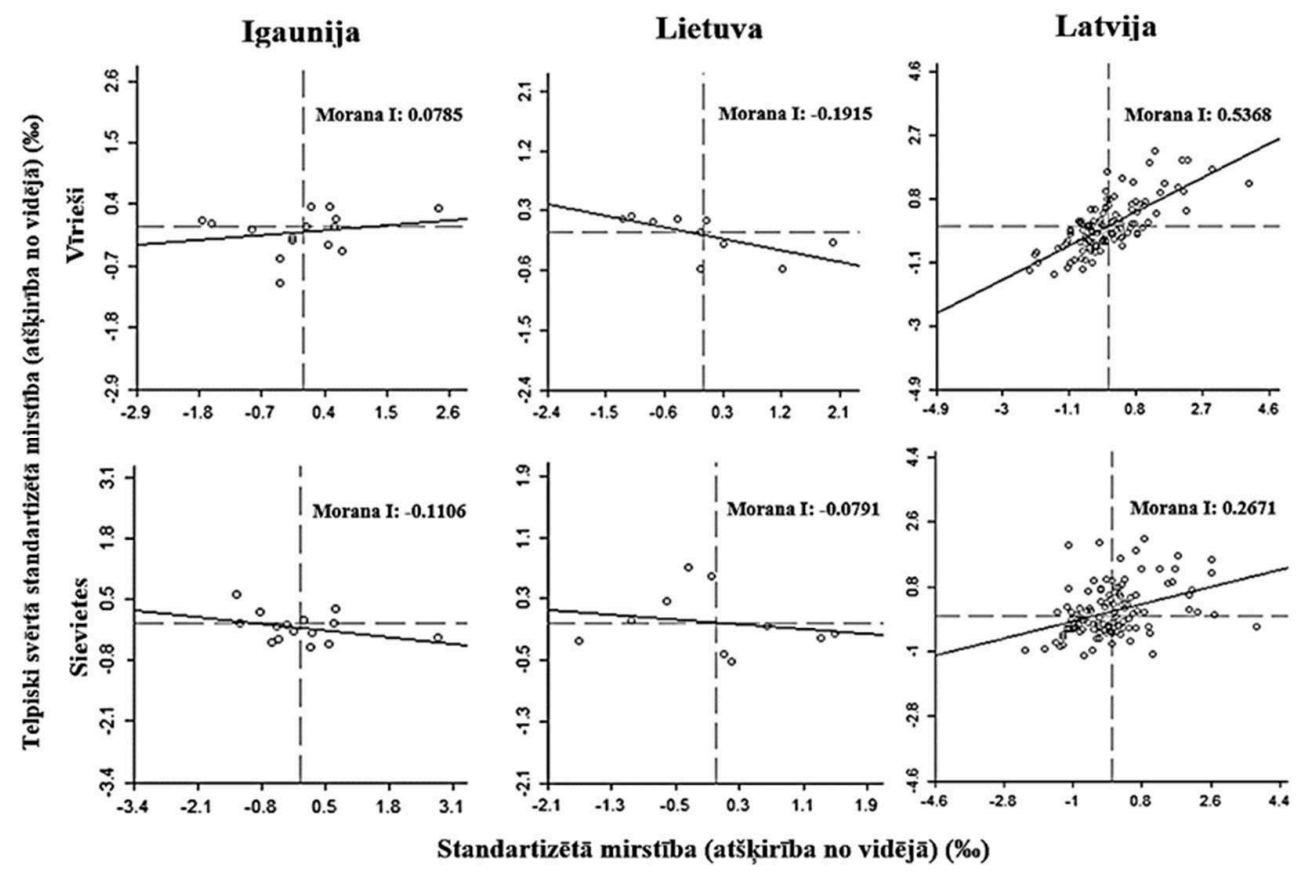

2. attēls. Baltijas valstu iedzīvotāju 2011. gada standartizētās mirstības Morana izkliedes diagramma pēc dzimuma grupām. Avots: CSP, Statistics Lithuania un Statistics Estonia datiem balstīti autora aprēķini

Aplūkojot izveidoto karti, var viegli pamanīt izteiktas atšķirības starp valstu reǵioniem, kā arī starp vīriešu un sieviešu mirstības līmeni noteiktajās teritorijās. Papildus kartes skaidri parāda vairāku vienveidīgu teritoriālo vienību klasteru veidošanos, kas liecina par to, ka pētāmais rādītājs ir pakḷauts noteiktai telpiskai autokorelācijai. 
2. attēls atspoguḷo iedzīvotāju standartizētās mirstības telpiskās autokorelācijas testa rezultātus Baltijas valstīs 2011. gadā atbilstoši dzimuma grupām.

Testa rezultāti norāda uz statistiski nozīmīgas telpiskās autokorelācijas klātbūtni Latvijas vīriešu mirstības datos, kas vairāk nekā divreiz pārsniedz šo pašu mirstības raksturlielumu sievietēm. N̦emot vērā Latvijas un pārējo divu Baltijas valstu teritoriālo vienību izmēra atšķirības, to telpiskās autokorelācijas testu rezultāti nav tieši salīdzināmi savā starpā. Tomēr iegūtie dati l̦auj izdarīt secinājumu par noteiktu līdzību starp Latvijas un Igaunijas vīriešu mirstības telpisko izkliedi, kā arī par pilnīgi pretēju situāciju Lietuvā, ko var izskaidrot ar mirstības "karsto punktu” esību valsts pretējās daḷās. Sieviešu mirstība Latvijā un Lietuvā ir pakḷauta daudz mazākai telpiskai autokorelācijai nekā vīriešu indikatori, bet Igaunijā demonstrē mēreni negatīvu līmeni.

\section{Secinājumi}

Standartizēto mirstības datu grafiskās un telpiskās analīzes rezultāti rāda, ka kopumā Latvijas un Lietuvas austrumu pierobežas, kā arī Igaunijas ziemeḷaustrumu teritoriālajās vienībās iedzīvotāju standartizētā mirstība ir nozīmīgi lielāka nekā pārējos reǵionos (novados / apriņ̧̧os). Savukārt Latviju ar Igauniju vieno pozitīvas vīriešu mirstības telpiskās autokorelācijas iezīmes, kas nav raksturīgas Lietuvai, kur ir novērota pretēja situācija. Svarīgi ir pieminēt arī to, ka līdzvērtīgi paaugstināts mirstības līmenis tika konstatēts arī reǵionos, kas atrodas pie iekšējām robežām starp Baltijas valstīm, ko var daḷeji izskaidrot gan ar šo teritoriju vēsturisko specifiku, gan ar esošu sociāli ekonomisko situāciju.

\section{Atsauces}

Anselin, L. (1995). Local indicators of spatial association - LISA. Geographical analysis, 27(2), 93-115.

Berzins, A., \& Zvidrins, P. (2011). Depopulation in the Baltic States. Lithuanian Journal of Statistics, 50(1), 39-48.

Centrālā statistikas pārvalde (CSP). Iedzīvotāji un sociālie procesi: http://data.csb.gov.lv/pxweb/lv/Sociala (02.02.2016)

Eglīte, P. (2008). Nedeklarētās izceḷošanas sekas un to rosinātā rīcība. Darbaspējīgo skaita mazināšanās Latvijā un iespējamie risinājumi. Apcerējumi par Latvijas iedzīvotājiem, No. 13. Riga: SIA LZA Ekonomikas institūts, 16-14.

Krisjane, Z. (2005). Latvia: a centre oriented country in transition. Muller B., Finka M., Lintz G. (eds.). Rise and decline of industry in Central and Eastern Europa. Berlin, Heidelberg, New York: Springer, 131-153.

Krūmiņš, J. (2006). Iedzīvotāju veselība, mirstība un mūža ilgums Latvijā: tendences, faktori, perspektīvas. Demogrāfiskā attīstība Latvijā 21. gadsimta sākumā. Rīga: Zinātne, 9-32.

Krumins, J., Jasilionis, D., Leinsalu, M., and Stankuniene V. (2009). Changes of Geographical Mortality Differences in the three Baltic Countrie during the Period of SocioEconomic Transformation. Poster presentation at the XXVI International Population Conference. Marrakech, 27 September - 2 October 2009: http://iussp2009.princeton.edu/papers/91432 (15.02.2016). 
Matthews, S. A., Parker, D. M. (2013). Progress in Spatial Demography. Demographic Research, 28(10), 271-312.

Statistics Estonia. Population and Regional Development in Estonia: http://www.stat.ee/publication-download-pdf?publication_id=39434 (04.02.2016).

Statistics Lithuania. Population and Social Statistics: http://osp.stat.gov.lt/en/temineslenteles 19 (03.02.2016).

Voss, P. R., White, K. C., Hammer, R. B. (2006). Explorations in spatial demography. Kandel W. A. \& Brown D. L. (eds) Population change and rural society. Netherlands: Springer, 407-429.

Zvidriņ̌š, P. (ed.) (2009). Demogrāfiskā attīstība Latvijas regionos. Rīga: LU Akadēmiskais apgāds.

\section{Summary}

During the last decade, depopulation issues have been widely discussed by both the academic and political communities of Latvia and the other Baltic States. Although scientific literature has sufficiently described the migration component of the depopulation processes in Latvia, the role of natural population movement - and specifically, population mortality - in the reduction of population numbers has received comparatively less attention due to low availability of relevant statistical and spatial data. In 2011, Latvia had its first Population and Housing Census after the completion of the 1999-2009 administrative-territorial reform. The census results have not only corroborated the previously estimated scale of the regional depopulation problem, but also provided an opportunity for a much more detailed regional demographic analysis on the level of individual municipalities. Therefore, using the 2011 census data, as well as other available statistical and spatial information, an indirect standardisation of the mortality rates in Latvian municipalities was conducted. In order to gauge the scale of similar demographic problems in the closest neighbouring countries, the mortality rates of Lithuanian and Estonian districts were also standardized. By adding the spatial data to the calculation results, opportunities for both graphical and spatial data analysis have been expanded. Results suggest significant differences in male and female mortality within multiple territorial units. It can also be concluded that male mortality is subject to a noticeable spatial autocorrelation across Latvian municipalities. 